\title{
A Correlation Between Leg Muscle Explosive Power And Ankles Coordination On The Shooting Accuracy In Soccer Games In Sukasari Village Club
}

\section{Hubungan Kekuatan daya ledak Otot Kaki dengan Koordinasi Pergelangan Kaki Pada Ketepatan Menembak Dalam Pertandingan Sepak Bola Di Klub Desa Sukasari}

\author{
Putu Krisna Aditya 1), Juwita ${ }^{2)}$, Supriyanto ${ }^{3)}$ \\ 1,2,3 Departemen Phsycal Education Study Program, Universitas Dehasen \\ Corresponding Author: : \\ juwitarhazes@unived.ac.id \\ Bengkulu, Bengkulu, Indonesia
}

\section{How to Cite :}

Aditya, Putu Krisna, Juwita \& Supriyanto. (2021). A Correlation Between Leg Muscle Explosive Power And Ankles Coordination On The Shooting Accuracy In Soccer Games In Sukasari Village Club. Hanoman Journal: Phsycal Education and Sport 2 (1) 2021 page: 7-12 DOI: https://doi.org/10.37638/hanoman.2.1.7-12

ARTICLE HISTORY Received [21 May 2021] Revised [23 May 2021] Accepted [21 June 2021]

Kata Kunci :

Daya ledak otot kaki,

koordinasi pergelangan kaki, ketepatan menembak

Keywords :

leg muscle strength, ankle coordination, shooting accuracy.
This is an open access article under the $C C-B Y-S A$ license

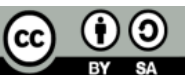

\section{ABSTRAK}

Tujuan dari penelitian ini adalah untuk mengetahui hubungan antara daya ledak otot tungkai dan koordinasi mata kaki dengan keakuratan menembak pada permainan sepak bola di klub Desa Sukasari. Metode yang digunakan dalam penelitian ini adalah metode kuantitatif korelasional. Populasi dalam penelitian ini adalah 20 atlet di Desa Sukasari, sedangkan sampel dalam penelitian ini adalah 20 atlet (semua). Instrumen dalam penelitian ini adalah tes Lompat Jauh Berdiri, Tes Sepak Bola Mitcel, dan Tes Menembak At The Ball. Persyaratan analisis data yang digunakan adalah uji normalitas Lillifors dan uji homogenitas. Analisis data yang digunakan adalah analisis korelasi product moment dengan taraf signifikansi 5\%. Berdasarkan hasil penelitian didapatkan bahwa terdapat hubungan yang signifikan antara daya ledak otot tungkai dan koordinasi pergelangan kaki $(X)$ terhadap akurasi menembak yang ditunjukkan dengan $r \times 1 \times 2 y=0,920>r(0,5)(20)=0,444$.

\section{ABSTRACT}

The purpose of this study is to determine the correlation between the explosive power of the leg muscles and the coordination of the ankles on the accuracy of shooting in soccer games in Sukasari Village club. The method used in this research is correlational quantitative method. The population in this study were 20 athletes in Sukasari village, while the sample in this study were 20 athletes (all). The instruments in this study were the Standing Long Jump test, the Mitcel Soccer test, and the At The Ball shooting test. The data analysis requirements used were the Lillifors normality test and the homogeneity test. The data analysis used was the 
product moment correlation analysis with a significance level of 5\%. Based on the results of the study, it was found that there was a significant relationship between the explosive power of the leg muscles and the coordination of the ankles $(X)$ on the shooting accuracy as indicated by $r \times 1 \times 2 y=0.920>r(0.5)(20)=0.444$.

\section{PENDAHULUAN}

Menjadi pemain sepakbola yang baik, pemain sepakbola memerlukan penguasaan teknik dasar. Hal ini dikarenakan penguasaan teknik dasar bermain sepakbola yang harus dikuasai oleh seseorang pemain sepak bola antara lain teknik dasar dribbling, heading, controling, passing dan shooting. Dari beberapa teknik dasar yang ada di atas teknik shooting merupakan salah satu teknik yang harus di kuasai oleh setiap pemain sepakbola. Shooting merupakan salah satu teknik yang selalu di gunakanuntuk mencetak gol dan melakukan penekanan ke jantung pertahanan lawan. Shooting adalah satu upaya yamg di gunakan untuk mencetak gol sebanyak-banyaknya kegawang lawan. Kemampuan setiap melakukan shooting harus selalu ditingkatkan guna untuk menghasilkan gol demi gol di setiap pertandingan.

Menendang bola merupakan salah satu teknik dasar yang penting dalam permainan sepakbola. Memperoleh kemenangan dalam suatu pertandingan yang merupakan tujuan utama pembinaan prestasi ditentukan oleh salah satunya melalui kemampuan menendang bola para pemainnya. Prinsip dasar permainan sepakbola adalah mencetak gol ke gawang lawan dan mencegah gol ke gawang sendiri. Selama permainan, segala kemampuan baik fisik, teknik, maupun taktik dan strategi dikerahkan dalam usaha untuk mencetak gol sebanyak-banyaknya ke gawang lawan, dan mencegah gawangnya sendiri kemasukan gol. Pemain sepakbola harus memiliki kemampuan teknik untuk memasukkan bola dengan baik. Penguasaan teknik menjadi dasar utama untuk mengembangkan mutu yang tinggi dalam suatu permainan dan pertandingan.

Dalam aktifitas olahraga dapat disebut sebagai motor penggerak dalam setiap aktifitas gerakan yang di lakukan guna untuk mendapatkan hasil yang ingin dicapai dan proses pencapaian prestasi semaksimal mungkin. Maka dari itu olahraga sepakbola sangat membutuhkan kekuatan otot baik itu kekuatan otot tungkai,kekutan otot paha pada saat sedang bermain sepakbola dan pada waktu melakukan shooting sepakbola. Kekuatan dalam melakukan shooting memiliki faktor yang sangat dominan dalam melakukan shooting pada saat bermain sepakbola maupun saat berlatih dalam shooting kegawang. Untuk mendapatkan kualitas shooting yang baik sangat membutuhkan latihan fisik yang terprogram dan dengan bimbingan pelatih untuk mengarahkan bagaimana dapat menghasilkan kekuatan otot tungkai untuk dapat melakuan shooting yang terarah dengan teknik yang benar, dengan menanamkan kepada pemain miliki mental untuk maju dan tekad untuk menang di setiap pertandingan.

8 | Aditya, Putu Krisna, Juwita \& Supriyanto. (2020). A Correlation Between Leg Muscle Explosive... 
Dalam permainan sepakbola Koordinasi mata kaki, Koordinasi yang diperlukan setiap pemain dalam bermain sepakbola adalah koordinasi anatara mata kaki, karena mata adalah pusat di mana pandangan melihat kondisi di sekitar lapangan serta peranan kaki seebagai penggolah bola pada saat melakukan shooting. Antara pandangan mata dan gerakan kaki dalam permaina sepakbola yang di domonasi dalam penggunaan kaki membuat peranan kekuatan otot tungkaki dan koordinasi mata kaki sangat penting.

Klub sepakbola yang terdapat di Desa Sukasari adalah salah satu tim yang ada di kabupaten Seluma Provinsi Bengkulu yang rutin melakukan pertandingan tingkat kecamatan dan umum yang ada di Provinsi Bengkulu. Klub ini merupakan para pemuda desa, klub ini melakukan latihan hari rabu, jumat dan minggu. Tim sepakbola Sukasari ini sangat didukung oleh pemerintahan desa dan memberikan sarana dan perasarana untuk klub sepakbola desa Sukasari.

\section{METODE PENELITIAN}

Adapun tempat penelitian dilapangan sepakbola Desa Sukasari kabupaten seluma. Sedangkan waktu penelitian yang peneliti telah melakukan penelitian yang dimulai pada bulan Mei, dan langkah-langkah yaitu dimulai dari pengambialan data, dan dilanjutkan analisis data. Penelitian ini termasuk jenis penelitian korelasional, dengan metode penelitian yang digunakan adalah metode survei.

\section{HASIL}

Hasil Pengukuran Kekuatan Otot Tungkai (Variabel $\mathrm{X}^{1}$ ). Deskriptif statistik data dari pengukuran 20 orang Kekuatan Otot Tungkai di Club Desa Sukasari didapat skor terendah (minimum) 34, skor tertinggi (maksimum) 80, rerata (mean) 2,33, , standar deviasi (SD) 0.14. Hasil Pengukuran Koordinasi Mata Kaki (Variabel X ${ }^{1}$ ). Deskriptif statistik data dari pengukuran 20 orang Koordinasi Mata Kaki di klub Desa Sukasari didapat skor terendah (minimum) 37, skor tertinggi (maksimum) 73, rerata (mean) 11,95, standar deviasi (SD) 2,23. Hasil tes Ketepatan Shooting (Variabel Y). Deskriftif statistik data Ketepatan Shooting di klub Desa Sukasari didapat skor terendah (minimum) 29, skor tertinggi (maksimum) 68 rerata (mean) 8,95, standar deviasi(SD) 2,85.

Berdasarkan hasil analisis tersebut di atas diperoleh koefisien korelasi antara Kekuatan Otot Tungkai dengan Koordinasi Mata kaki sebesar 0,872 bernilai positif, artinya semakin tinggi nilai Kekuatan Otot Tungkai, maka semakin baik nilai Koordinasi Mata kaki Koordinasi Mata kaki. Uji keberartian koefisien korelasi tersebut dilakukan dengan cara mengonsultasi harga $r$ hitung dengan $r$ tabel, pada $a=5 \%$ dengan $\mathrm{N}=20$ diperoleh $r$ tabel sebesar 0,444 . Koefisien korelasi antara $r \times 1 \times 2$ $=0,872>(0.05)(20)=0,444$, berarti koefisien korelasi tersebut signifikan. Hipotesis yang berbunyi “Ada hubungan yang signifikan antara Kekuatan Otot Tungkai dengan 
Koordinasi Mata kaki di klub Desa Sukasari", diterima. Artinya Dengan demikian hipotesis akhir $(\mathrm{Ha})$ di terima dan hipotesis awal $(\mathrm{Ho})$ di tolak

Berdasarkan hasil analisis tersebut di atas diperoleh koefisien korelasi Kekuatan otot tungkai dan Koordinasi Mata kaki terhadap ketepatan Shooting sebesar Rx1x2y = 0,920. Uji keberartian koefisien korelasi tersebut dilakukan dengan cara harga rhitung dengan rtabel pada $\alpha=5 \%$ dengan $n=20$ diperoleh rtabel sebesar 0,444 Karena koefisien korelasi antara $r \times 1 \times 2=0,920>r(0,5)(20)=0,444$ berarti hubungan kekuatan otot tungkai dan Koordinasi Mata kaki terhadap ketepatan Shooting di klub Desa Sukasari adalah signifikan. Dengan demikian hipotesis yang berbunyi "ada hubungan yang kuat antara kekuatan otot tungkai dan koordinasi mata kaki terhadap ketepatan shooting", diterima.

\section{PEMBAHASAN}

Penelitian ini bertujuan untuk mengetahui korelasi antara hubungan kekuatan otot tungkai dan Koordinasi Mata kaki terhadap ketepatan Shooting di klub Desa Sukasari $r \times 1 \times 2=0,920>r(0,5)(20)=0,444$. Berdasarkan hasil analisis tersebut di atas diperoleh koefisien korelasi antara Kekuatan Otot Tungkai dengan Ketepatan Shooting bernilai positif, artinya semakin tinggi nilai Kekuatan Otot Tungkai, maka semakin baik nilai Ketepatan Shooting. Kekuatan otot tungkai adalah kemampuan suatu otot atau sekelompok otot tungkai untuk mengatasi beban atau tahanan. Hal ini tentu juga berlaku untuk mempermudah mempelajari Ketepatan Shooting Melihat penjelasan tentang hasil analisis data dan teori di atas, dapat dipahami bahwa kekuatan dan koordinasi mata kaki berhubungan secara signifikan dengan ketepatan Shooting dan kebenarannya terbukti secara empiris. Dari hasil penelitian ini menunjukkan bahwa kekuatan otot tungkai dan koordinasi mata kaki menjadi variabel yang dapat menguatkan tingkat Ketepatan Shooting di klub Desa Sukasari.

\section{KESIMPULAN DAN SARAN}

Terdapat hubungan yang signifikan antara Kekuatan Otot Tungkai dengan Ketepatan Shooting di klub Desa Sukasari", dengan Koefisien korelasi antara rx1y = $0,822>(0.05)(20)=0,444$, berarti koefisien korelasi tersebut signifikan. Terdapat hubungan yang signifikan antara hubungan antara Koordinasi Mata kaki dengan Ketepatan Shooting di klub Desa Sukasari, dengan korelasi antara rx2y =0,919 > $(0.05)(20)=0,444$, berarti koefisien korelasi tersebut signifikan. Terdapat hubungan yang signifikan antara Kekuatan Otot Tungkai dengan Koordinasi Mata kaki di klub Desa Sukasari dengan Koefisien korelasi antara $r \times 1 \times 2=0,872>(0.05)(20)=0,444$, berarti koefisien korelasi tersebut signifikan. Terdapat hubungan yang signifikan antara kekuatan otot tungkai dan Koordinasi Mata kaki terhadap ketepatan Shooting

10 | Aditya, Putu Krisna, Juwita \& Supriyanto. (2020). A Correlation Between Leg Muscle Explosive... 
di klub Desa Sukasari dengan koefisien korelasi antara $r \times 1 \times 2 y=0,920>r(0,5)(20)=$ 0,444 berarti koefisien korelasi tersebut signifikan.

Bagi pelatih, selalu menjaga dan melatih Kekuatan Otot Tungkai dan Koordinasi mata kaki karena latihan tersebut akan mempengaruhi dan meningkatkan ketepatan Shooting. Bagi siswa agar menambah latihan-latihan kekuatan dan koordinasi mata kaki lain yang mendukung dalam mengembangkan dan meningkatkan ketepatan Shooting.

\section{DAFTAR PUSTAKA}

1. Ali Maksum.( 2007). Tes dan pengukuran dalam olahraga. Surabaya: Universita Negeri Surabaya

2. Anas Sudijono. (2013). Pengantar Statistik Pendidikan. Jakarta: Rajawali Pers

3. Depdiknas. (1995). Kurikulum Pendidikan Mata Pelajaran Pendidikan Jasmani. Jakarta: Depdikbud.

4. Djoko Pekik Irianto. (2002). Pedoman Praktis Berolahraga untuk Kebugaran dan Kesehatan. Yogyakarta : Andi Offset.

5. Gifford. (2002). "Sepakbola Panduan Lengkap Untuk Permainan Yang Indah." Jakarta. Erlangga

6. Harsono. (1988). Coaching dan Aspek-Aspek Psikologis Dalam Coaching, CV. Tambak Kusuma, Jakarta.

7. Hurlock, E. (1999). Perkembangan Anak. Jilid Ke-2. (Medmeitasari Tjandrasa. Terjemahan). Jakarta: Airlangga.

8. Ismaryati (2006) Tes dan Pengukuran Olahraga. Jakarta.

9. Komarudin. (2011). Dasar Gerak Sepak Bola. Yogyakarta: FIK UNY

10. Mielke. (2007). Dasar-dasar Sepakbola. Bandung: Pakar Raya.

11. Muhajir (2004).Pendidikan Jasmani Teori Dan Praktek SMA.Erlanga.

12. Ngatman. (2007). Kriteria-Kriteria Penyusunan Alat Evaluasi Dalam Pengajaran Pendidikan Jasmani. Yogyakarta: FIK UNY.

13. Rusli Lutan, dkk. (2000). Dasar dasar Kepelatihan. Jakarta: Departemen Pendidikan dan Kebudayaan.

14. Salim. (2007). Teori dan Paradigma Penelitian Sosial. Yogyakarta: Tiara Wacana.

15. Soedjono dkk. (1979). Sepakbola. Direktorat JenderalPendidikan Dasar Dan Menengah.

16. Sugiyono. (2006). Statistik Untuk Penelitian. Bandung: Alfabeta.

17. Suharno HP. (1985). Ilmu Kepelatihan Yogyakarta: IKIP Yogyakarta

18. Suharsimi Arikunto. (2006). Prosedur Penelitian. Jakarta: PT Asdi

19. Sucipto, dkk. (2000). Sepak Bola. Jakarta. Departemen Pendidikan Nasional.

20. Sukatamsi, (1997). Teknik Dasar Bermain Sepak Bola. : Tiga Serangkai 
21. Sukadiyanto. (2002). Pengantar Teori dan Metodologi Melatih Fisik. Universitas Negeri Yogyakarta: Fakultas IImu Keolahragaan.

22. Sukintaka. (1992). Permainan dan Metodik Buku III. Jakarta : PT Firma Resama Sutrisno Hadi. (2004). Statistik Jilid 2. Yogyakart: Andi Offset. 